\title{
The application and testing of diatom-based indices of stream water quality in Chinhoyi Town, Zimbabwe
}

\author{
Taurai Bere ${ }^{1 *}$, Tinotenda Mangadze ${ }^{1}$ and Tongayi Mwedzi ${ }^{1}$ \\ ${ }^{1}$ Chinhoyi University of Technology, Department of Wildlife and Safari Management, Off Harare-Chirundu Rd, P. Bag 7724, Chinhoyi, Zimbabwe
}

\section{ABSTRACT}

\begin{abstract}
Aquatic ecosystem biomonitoring tools are largely lacking for many developing countries, resulting in adoption of tools developed from other countries/regions. In many instances, however, the applicability of adopted tools to the new system has not been explicitly evaluated. The objective of this study was to test the applicability of foreign diatom-based water quality assessment indices to urban streams in Zimbabwe, with the view of stimulating research to develop improved approaches for assessing ecological integrity of lotic systems in the country. The study evaluated the relationship between measured water quality variables and diatom index scores. The study found a high degree of concordance between water quality variables and diatom index scores. Thus, the indices proved useful in providing an indication of the quality of the investigated waters. This could be attributed to the occurrence of many widely distributed diatom species that have similar environmental tolerances to those recorded elsewhere. Diatom indices which exhibited consistent classifications and strong correlations with water quality variables such as Trophic Index, Saprobic Index, Pampean Diatom Index, Biological Index of Water Quality and Leclercq Index are recommended for use in the country. However, ecological requirements of some diatom species from Zimbabwe need to be clarified and incorporated in a diatom-based water quality assessment protocol unique to the country.
\end{abstract}

Keywords: biological monitoring, pollution, benthic diatoms, biotic indices

\section{INTRODUCTION}

The relation between diatom communities and environmental variables in aquatic systems is robust and quantifiable (Wehr and Sheath, 2003; Azim et al., 2005; Bere and Tundisi, 2010a, 2010b; 2011a). Each particular species requires different structural, physical and chemical characteristics intrinsic to its habitat. Whenever these characteristics are subject to slight variations, due to natural or anthropogenic activities, associated diatom communities respond rapidly, often changing in both taxonomic composition and biomass (Wehr and Sheath, 2003; Azim et al., 2005; Bere and Tundisi, 2009; Lavoie et al., 2008; Smucker and Vis, 2011; Stenger-Kovacs et al. 2013). Thus, pollution-monitoring programmes routinely include the examination of diatoms to investigate the water quality of aquatic systems (Watanabe et al., 1986; Descy and Coste, 1991; Kelly and Whitton, 1995; Prygiel et al., 1996; Biggs and Kilroy, 2000; Lobo et al., 2004; Taylor et al., 2007a, 2007b; Phiri et al., 2007; Lavoie et al., 2008; Bere and Tundisi, 2011c, 2011d, 2011e).

Biological monitoring is a fast and cost-effective approach for assessing the effects of environmental stressors, making it a particularly essential tool for the management of rivers in developing countries (McCormick and Cairns, 1994; Taylor et al., 2007a; Harding et al., 2005, Bere and Tundisi, 2010a). Unfortunately, diatom-based biological monitoring tools are largely lacking for many developing countries, resulting in the adoption of tools developed from other countries/regions. In many instances where these tools are adopted, their applicability to the new system has not been explicitly evaluated. However, there is evidence that diatom metrics or indices

\footnotetext{
To whom all correspondence should be addressed.

용 +263777 163 094; e-mail: taubere@yahoo.com; tbere@cut.ac.zw Received 29 July 2013; accepted in revised form 30 June 2014.
}

developed in one geographic area are less successful when applied in other areas (Pipp, 2002). This is due not only to the floristic differences among regions (Potapova and Charles, 2002; Rimet et al., 2004; Taylor et al., 2007a; Chessman and Townsend, 2010), but also to the environmental differences that modify species responses to water-quality characteristics (Potapova and Charles, 2007). Endemic diatom species may also occur in different regions, necessitating development of region-specific indices. Thus, strict testing of these borrowed indices is required to ensure that diatom index scores give a realistic reflection of the specific type of environmental pollution being tested (Taylor et al., 2007a).

The use of diatoms as indicators of water quality changes has relatively few precedents in Zimbabwe. Phiri et al. (2007) studied periphytic diatoms attached to the leaves of the submerged macrophyte Vallisneria aethiopica in the shallow waters of the Sanyati Basin in Lake Kariba, Zimbabwe. They concluded that diatoms may potentially be useful in assessing ecological conditions or the impact of human activities within the shallow marginal waters of the lake. Besides this study, there are no other detailed studies exploring the potential use of diatoms as indicators of water quality in aquatic systems. Diatom communities and their ecological requirements have largely been unexplored in the study region, hampering the use of diatoms as ecological indicators. The objectives of the present study were twofold: (i) to assess epilithic diatom community structure and composition in streams in relation to environmental conditions, and (ii) to test the applicability of the diatom-based water quality assessment indices developed in other regions, and calculated by the OMNIDIA version 5.3 software, to the study area. Diatom index scores were calculated and correlated to concurrent physical and chemical water quality data. The results of these correlation analyses were compared to results obtained in similar studies carried out elsewhere, e.g., in South America (Brazil), Europe and South Africa. 


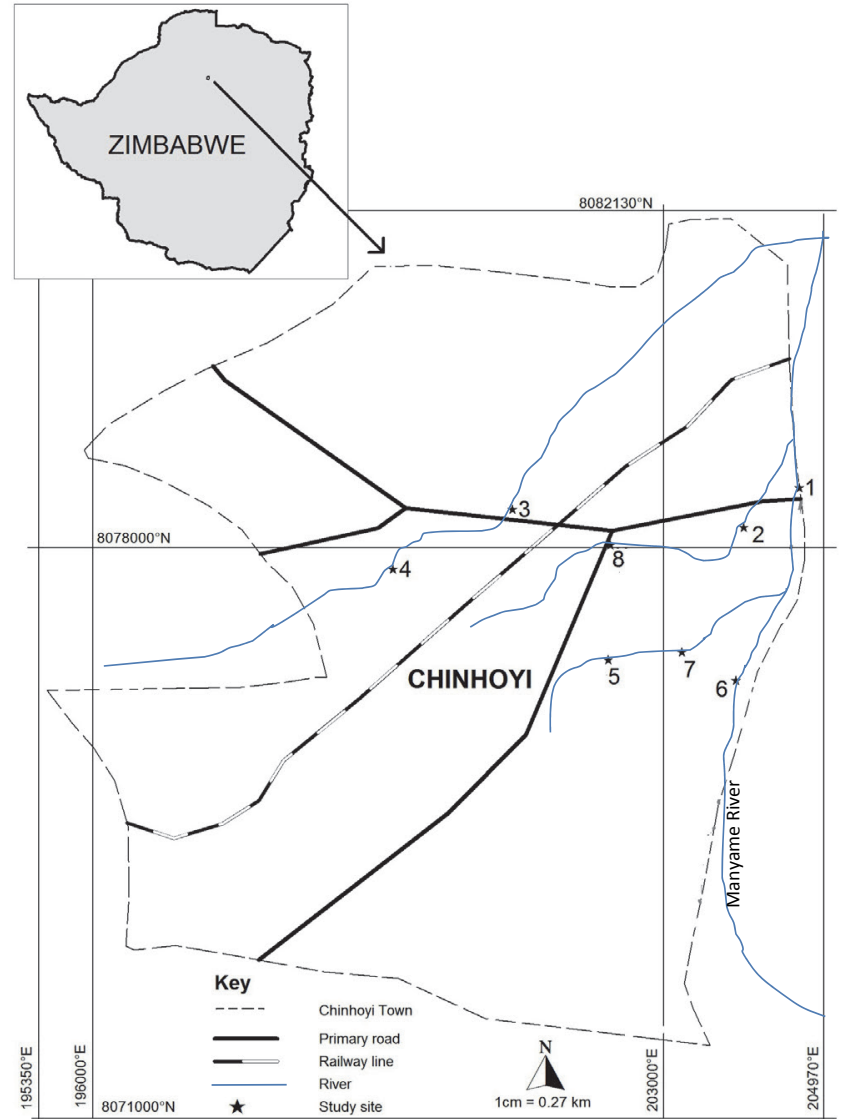

Figure 1

Location of sampling sites in the study area

\section{MATERIALS AND METHODS}

\section{Study area and study design}

The study area is shown in Fig. 1. The area has average annual temperature of around $24.5^{\circ} \mathrm{C}$, with a mean monthly maximum of $29.9^{\circ} \mathrm{C}$ recorded in October and November and a mean monthly minimum of $18.9^{\circ} \mathrm{C}$ recorded in July. In 2012, the population of Chinhoyi was estimated at 79368 inhabitants by the Zimbabwe National Statistics Agency (ZNSA). The municipality of Chinhoyi Town does not have an adequate system of sorting and disposal of waste. Streams in the study area therefore receive untreated or semi-treated effluent from various domestic and industrial sources as well as other diffuse sources as they pass through Chinhoyi. The city was also expanded without taking into account environmental, geographical and topographical factors, leading to deforestation, erosion and siltation. This unplanned growth, typical of many Zimbabwean cities, results in stream health deterioration, loss of primary vegetation and eutrophication, among other problems.

Eight sites were established in different streams draining Chinhoyi Town. The criterion for selecting sampling sites was to enable evaluation of the impact of breakdown in municipal service delivery (especially sewage treatment) on water quality and the associated diatom communities in the study streams. Site 1 was located downstream on the Manyame River while Site 6 was located upstream on the same river, in a relatively less-polluted area. Large flow volumes in the Manyame River (the upper reaches of which drain less-polluted commercial farms) are expected to have a dilution effect on pollutants at Sites 1 and 6. Sites 2, 5 and 7 were located just after sewage effluent discharge points. Sites 3, 4 and 8 were located in the town centre where uncollected garbage and effluent from broken sewage pipes finds its way into the stream. All of the sites were sampled 5 times on the following dates: 21/01/2012, 04/03/2012, 16/05/2012, 30/07/2012 and 27/08/2012.

\section{Environmental variables}

At each site, dissolved oxygen (DO), electrical conductivity, temperature, $\mathrm{pH}$ and turbidity were measured using appropriate portable probes. The percentage riparian vegetation cover was visually estimated at each site. Water samples were collected at each site into acid-cleaned polyethylene containers (American Public Health Association, APHA, 1988). In the laboratory, the concentrations of ammonium, nitrites, phosphates, iron and manganese were determined using a Hach DR/2010 spectrophotometer (Hach Company, 1996-2000). Calcium levels were determined by ethylenediamine tetra-acetic acid (EDTA) titrimetric method following APHA (1988).

\section{Biological components and indices used}

At each site, epilithic diatom samples were sampled by brushing stones with a toothbrush. Prior to sampling of epilithic surfaces, all substrata were gently shaken in stream water to remove any loosely attached sediments and non-epilithic diatoms. At least 5 pebble- to cobble-sized stones were randomly collected at each sampling site and brushed, and the resulting diatom suspensions were pooled to form a single sample, which was then put in a labelled plastic bottle. In the laboratory, sub-samples of the diatom suspensions were cleaned of organic material using wet combustion with concentrated sulphuric acid and mounted in Naphrax (Northern Biological supplies Ltd., UK, RI=1.74), following Biggs and Kilroy (2000). Three replicate slides were prepared for each sample. Around 400 valves per sample (based on counting efficiency determination method by Pappas and Stoermer (1996)) were identified and counted using a phase-contrast light microscope $(\times 1,000$; Leica Microsystems, Wetzlar GmbH, Type - 020-519.503 LB30T, Germany). The diatoms were identified to species level based mainly on studies from South Africa (Taylor et al., 2007c), as well as other studies (e.g. Metzeltin and Lange-Bertalot, 1998, 2007).

The diatom species counts were entered into the diatom database and index calculation tool OMNIDIA version 5.3 (Lecointe et al., 1993).The following indices were calculated and tested: the Artois-Picardie Diatom Index or APDI (Prygiel et al., 1996); the Eutrophication/Pollution Index or EPI (Dell'Uomo, 1996); the Biological Diatom Index or BDI (Lenoir and Coste, 1996); Schiefele and Schreiner's index or SHE (Schiefele and Schreiner, 1991); the Saprobic Index or SI (Rott et al., 1997); the Trophic Index or TI (Rott et al., 1999); the Watanabe index or WAT (Watanabe et al., 1986); the Specific Pollution Sensitivity Index or SPI (Coste in Cemagref, 1982); the Sládeček's Index or SLA (Sládeček, 1986); Descy’s Pollution Index or DES (Descy, 1979); Leclercq or IDSE (Leclerq and Maquet, 1987); the Generic Diatom Index or GDI (Coste and Ayphassorho, 1991); the Commission of Economical Community Index or CEC (Descy and Coste, 1991); the Trophic Diatom Index or TDI (Kelly and Whitton, 1995); the Pampean Diatom Index or PDI (Gómez and Licuirsi, 2001) and 
TABLE 1

The mean $(n=5)$ and standard deviation of physical and chemical variables recorded at all of the sites during the study period.

\begin{tabular}{|l|c|c|c|c|c|c|c|c|}
\hline Site & $\mathbf{1}$ & $\mathbf{2}$ & $\mathbf{3}$ & $\mathbf{4}$ & $\mathbf{5}$ & $\mathbf{6}$ & $\mathbf{7}$ & $\mathbf{8}$ \\
\hline Temperature $\left({ }^{\circ} \mathrm{C}\right)$ & $22.8 \pm 4.6$ & $22.6 \pm 3.1$ & $19.3 \pm 4.5$ & $19.8 \pm 4.4$ & $21.1 \pm 4.1$ & $23.3 \pm 3.7$ & $21.9 \pm 3.8$ & $20.9 \pm 3.6$ \\
\hline Conductivity $\left(\mu \mathrm{S} \cdot \mathrm{cm}^{-1}\right)$ & $31.0 \pm 2.9$ & $85.0 \pm 14.3$ & $68.0 \pm 2.3$ & $70.2 \pm 15.6$ & $40.4 \pm 6.9$ & $30.4 \pm 2.3$ & $68.2 \pm 17.2$ & $58.5 \pm 3.5$ \\
\hline $\mathrm{DO}\left(\mathrm{mg} \cdot \ell^{-1}\right)$ & $7.2 \pm 0.5$ & $3.0 \pm 0.8$ & $5.5 \pm 0.7$ & $6.1 \pm 0.7$ & $5.4 \pm 0.6$ & $7.1 \pm 0.3$ & $3.6 \pm 1.1$ & $6.0 \pm 0.6$ \\
\hline $\mathrm{pH}$ & $7.8 \pm 0.3$ & $7.0 \pm 0.1$ & $7.3 \pm 0.0$ & $7.4 \pm 0.2$ & $7.4 \pm 0.1$ & $7.7 \pm 0.1$ & $7.1 \pm 0.1$ & $7.5 \pm 0.2$ \\
\hline Turbidity $(\mathrm{NTU})$ & $1.1 \pm 0.3$ & $61.3 \pm 17.7$ & $4.0 \pm 1.8$ & $3.5 \pm 2.1$ & $2.2 \pm 1.6$ & $1.5 \pm 0.7$ & $37.2 \pm 6.7$ & $2.7 \pm 1.8$ \\
\hline Nitrite $\left(\mathrm{mg} \cdot \ell^{-1}\right)$ & $0.1 \pm 0.1$ & $15.2 \pm 8.1$ & $0.8 \pm 1.5$ & $0.9 \pm 1.3$ & $0.8 \pm 1.5$ & $0.5 \pm 0.8$ & $11.1 \pm 6.6$ & $0.5 \pm 0.8$ \\
\hline Ammonium $\left(\mathrm{mg} \cdot \ell^{-1}\right)$ & $0.3 \pm 0.2$ & $9.6 \pm 8.2$ & $0.6 \pm 0.3$ & $0.4 \pm 0.3$ & $2.6 \pm 3.9$ & $1.9 \pm 0.4$ & $8.1 \pm 8.3$ & $1.0 \pm 1.0$ \\
\hline Phosphate $\left(\mathrm{mg} \cdot \ell^{-1}\right)$ & $<0.1$ & $3.3 \pm 5.8$ & $<0.1$ & $<0.1$ & $0.1 \pm 0.2$ & $0.3 \pm 0.6$ & $2.2 \pm 2.6$ & $0.3 \pm 0.5$ \\
\hline Calcium $\left(\mathrm{mg} \cdot \ell^{-1}\right)$ & $4.0 \pm 4.2$ & $4.2 \pm 2.0$ & $6.8 \pm 1.3$ & $9.1 \pm 1.1$ & $3.9 \pm 1.2$ & $4.3 \pm 2.0$ & $5.2 \pm 1.2$ & $5.8 \pm 0.6$ \\
\hline Iron $\left(\mathrm{mg} \cdot \ell^{-1}\right)$ & $0.04 \pm 0.05$ & $1.1 \pm 0.56$ & $0.20 \pm 0.20$ & $0.03 \pm 0.04$ & $0.1 \pm 0.15$ & $0.20 \pm 0.29$ & $0.4 \pm 0.37$ & $0.01 \pm 0.01$ \\
\hline Manganese $\left(\mathrm{mg} \cdot \ell^{-1}\right)$ & $0.02 \pm 0.04$ & $1.04 \pm 1.27$ & $0.22 \pm 0.40$ & $0.13 \pm 0.29$ & $0.57 \pm 1.04$ & $<0.02$ & $0.51 \pm 0.46$ & $<0.02$ \\
\hline Canopy cover $(\%)$ & 10 & 15 & 90 & 60 & 45 & 5 & 55 & 75 \\
\hline
\end{tabular}

the Biological Index of Water Quality or BIWQ (Lobo et al., 2004). All of these indices, except CEC, SHE, TDI and WAT index, are based on the formula of Zelinka and Marvan (1961).

\section{Statistical analysis}

The available environmental data consisted of 12 physical and chemical variables (Table 1). After testing for homogeneity of variances (Levene's test, $p<0.05$ ) and normality of distribution (Shapiro-Wilk test, $p<0.05$ ), it was evident that the distributions of conductivity and turbidity were positively skewed; therefore these distributions were log transformed (Zar, 1984). Two-way analysis of variance (two-way ANOVA) with Tukey's Honestly Significant Difference (HSD) pair-wise comparison test was used to compare means of environmental variables among the sites sampled and among the five sampling periods. Pearson's correlation was used to determine the relationship between the calculated index scores and measured physical and chemical water quality data. Pearson correlation, ANOVA, Levene's test and the Shapiro-Wilk test were performed using Palaeontological Statistics (PAST) software version 2.16 (Hammer et al., 2012).

The original diatom data set consisted of 101 diatom species. Diatom counts from each site were expressed as relative abundances. Input for multivariate analysis included the diatom taxa that were present in a minimum of 2 samples and had a relative abundance of $\geq 1 \%$ in at least 1 sample. This was done in order to eliminate the effects of rare species. Of the 101 diatom taxa recorded at 21 sites sampled, 45 met this criterion. Multivariate data analyses were performed on the combined diatom data set to explore the main gradients of floristic variation and to detect and visualise similarities in diatom samples. Preliminary de-trended correspondence analysis (DCA) was applied on the diatom data set to determine the length of the gradient. The DCA revealed that the gradient was greater than 3 standard deviation units, justifying the use of unimodal ordination techniques (Ter Braak and Verdonschot, 1995). Thus, canonical correspondence analysis (CCA) was performed to relate diatom community structure to simultaneous effects of predictor environmental variables, and to explore the relationship amongst and between species and predictor variables. Preliminary CCA identified collinear variables and selected a subset on inspection of variance inflation factors $(\mathrm{VIF}<20$; Ter Braak and Šmilauer, 2002). Monte Carlo permutation tests
(999 unrestricted permutations, $p \leq 0.05$ ) were used to test the significance of the axis and hence determine if the selected environmental variables could explain nearly as much variation in the diatom data as all 12 environmental variables combined. DCA and CCAs were performed using CANOCO version 4.5 (Ter Braak and Šmilauer, 2002).

\section{RESULTS}

\section{Physico-chemical variables}

The values of physical and chemical variables measured in the study area during the study period are shown in Table 1. Temperature was significantly lower (ANOVA, $p<0.05$ ) in the winter months, May and June, compared to the rest of the months. There were no significant differences in temperature among sampling sites (ANOVA, $p>0.05$ ) for all of the sampling periods, though Sites 3,4 and 8 , with significantly high vegetation cover (ANOVA, $p<0.05$ ), generally tended to be cooler compared to the rest of the sites. No significant differences were observed in conductivity, $\mathrm{DO}, \mathrm{pH}$, turbidity, nitrite, ammonia, phosphate, calcium, iron and manganese levels among the sampling periods. The $\mathrm{pH}$ did not differ significantly among sites (ANOVA, $p>0.05$ ), though it tended to be generally low at Sites 2 and 7 compared to the rest of the sites. Conductivity, turbidity, nitrite, ammonia, phosphate and manganese levels were significantly higher at Sites 2, 5 and 7 compared to the rest of the sites (ANOVA, $p<0.005$ ), while DO was significantly lower at Sites 2 , 5 and 7 compared to the rest of the sites.

\section{Community composition}

A total of 101 diatom species belonging to 35 genera were recorded in the 40 diatom samples collected. All of the sites were subject to some form of pollution (agricultural or urban); hence, species distribution was strongly biased towards those that are cosmopolitan and tolerant of elevated or slightly elevated levels of pollution. The results of the CCA are presented in Fig. 2. The first four axes of the selected exploratory variables accounted for $83.24 \%$ of the total variance in the community data (Table 2). Axis 1 and 2 significantly explained $27.72 \%$ and $24.08 \%$, respectively, of the diatom species variance (Table 2; Monte Carlo unrestricted permutation, $p<0.05$ ). Conductivity and ammonium (the latter was positively correlated with 


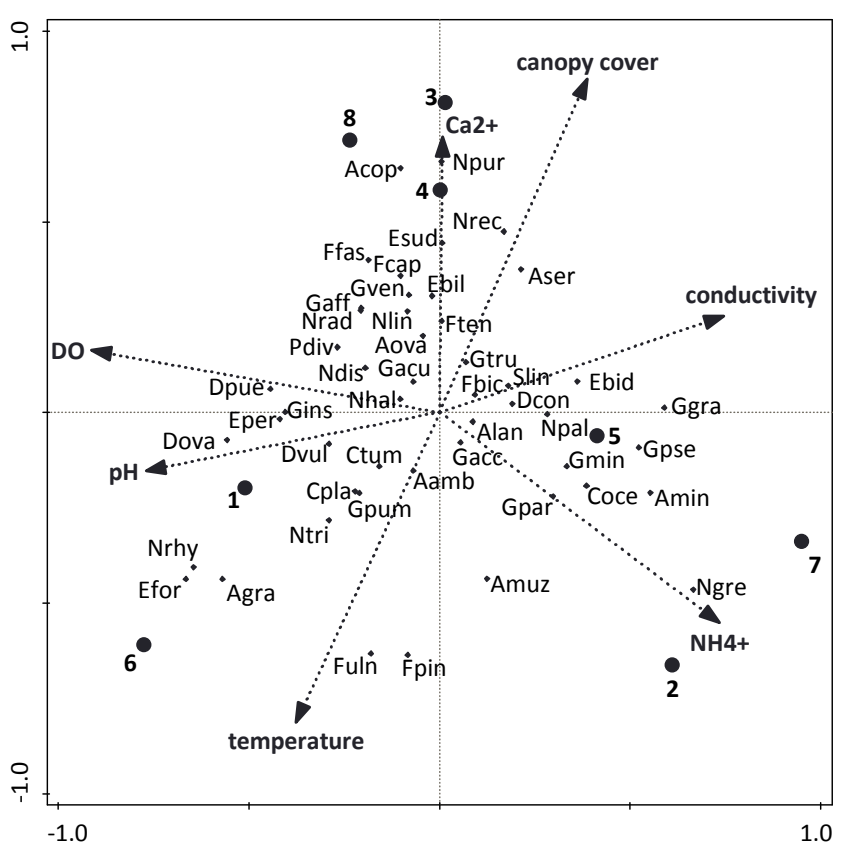

Figure 2

$C C A$ tri=plot showing the relationship between measured environmental variables and some diatom species in streams draining Chinhoyi Town. Acronyms are presented in Table 3.

turbidity, nitrite, phosphate and manganese) were positively associated with the first axis while $\mathrm{DO}, \mathrm{pH}$ and temperature were negatively associated with the first axis. Temperature and calcium levels were negatively and positively associated, respectively, with the second axis.

CCA Axes 1 and 2 separated the sites into 3 groups. The first group consisted of highly polluted Sites 2, 5 and 7 that were positively and negatively associated with the first and second axis, respectively (Fig. 2). These sites were associated with high ammonium (which was positively correlated with turbidity, nitrite, phosphate and manganese) and low $\mathrm{pH}$ and DO levels. Diatom species characterising these sites include species such as Achnanthidium cf. minutissimum, Aulacoseira muzzanensis (Meister) Krammer, Cyclotella ocellata Pantocsek, Gomphonema parvulum (Kützing) Cleve, G. gracile Ehrenberg, G. Pseudoaugur Krammer, Navicula gregalis Cholnoky and Nitzschia palea (Kützing) Smith.

The second group consisted of less polluted Sites 1 and 6 that were negatively associated with the first and second axis. These sites were associated with higher $\mathrm{pH}$, temperature and DO and had low vegetation cover, conductivity and ammonium levels. Diatom species characterising these sites include species such as Aulacoseira granulata (Ehrenberg) Simonsen, Cymbella tumida (Brébisson) Van Heurck, Cocconeis placentula
Ehrenberg, Eunotia formica Ehrenberg, Encyonema perpusillum (Cleve) Mann, Fragilaria pinnata Ehrenberg, Fragilaria ulna (Nitzsch) Lange-Bertalot, Gomphonema pumilum Reichardt \& Lange-Bertalot and Navicula rhynchocephala Kützing.

The third group consisted of medium polluted Sites 3, 4 and 8 that were positively associated with the second axis. These sites were associated with high vegetation cover and high calcium levels and had low temperature and $\mathrm{pH}$. Nutrient levels were generally low compared to those of Sites 2, 5 and 7. These sites were associated with such species as Amphora copulata (Kützing) Schoeman \& Archbald, Amphora ovalis (Kützing) Kützing, Eunotia bidentula Smith, Eunotia bilunaris (Ehrenberg) Mills, Eunotia sudetica Müller, Tabularia fasciculata (Agardh) Williams \& Round, Fragilaria tenera (Smith) Lange-Bertalot, Gomphonema affine Kützing, Gomphonema venusta Passy, Kociolek \& Lowe, Navicula radiosa Kützing, Nitzschia dissipata (Kützing) Grunow, Nitzschia linearis (Agardh) Smith, Nitzschia pura Hustedt and Surirella linearis Smith.

\section{Indices}

Of the 101 diatom species that were recorded during this study, 77 were entered into OMNIDIA for calculation of indices. The results of the diatom index scores generated for the sites sampled in streams draining Chinhoyi Town are shown in Table 4. Most of the indices classified the sites into broadly similar categories to those based on environmental variables (Table 1) and CCA (Fig. 2); with Sites 2, 5 and 7 generally being classified as highly polluted, Sites 3,4 and 8 being classified as moderately polluted and 1 and 6 being classified as less polluted. Inconsistencies in classification were observed for CEE, APDI, SLA, PT, WAT, GDI and DICH indices that tended to over- or under-estimate the water quality.

The results of the correlation analysis between measured environmental variables and diatom index scores generated for sites sampled during this study are presented in Table 5. Temperature and vegetation cover were generally significantly correlated with fewer index scores compared to the rest of the environmental variables. Turbidity, $\mathrm{DO}, \mathrm{pH}$ and ions associated with eutrophication, $\mathrm{NO}_{2}{ }^{-} \mathrm{NH}_{4}{ }^{+}$and $\mathrm{PO}_{4}^{3-}$, were significantly correlated with almost all of the index scores $(p<0.05)$. The APDI and the CEE indices had the weakest correlation with general water quality variables while other indices had fairly good correlation with water quality variables, with the TI index having the strongest correlations.

\section{DISCUSSION}

\section{Community structure in relationship to environmental variables}

Based on physical and chemical variables, pollution levels, especially eutrophication, differed among the sites sampled

\begin{tabular}{|l|c|c|c|c|}
\hline \multicolumn{4}{|c|}{ TABLE 2 } \\
Summary of CCA for streams draining Chinhoyi Town \\
\hline \multirow{2}{*}{ Statistic } & \multicolumn{4}{c|}{ Axis order } \\
\cline { 2 - 5 } & $\mathbf{1}$ & $\mathbf{2}$ & $\mathbf{3}$ & $\mathbf{4}$ \\
\hline Eigenvalue & 0.24 & 0.21 & 0.16 & 0.11 \\
\hline Explained variation (\%; cumulative) & 23.54 & 44.00 & 59.77 & 70.70 \\
\hline Psedo-canonical correlation & 0.99 & 0.99 & 0.99 & 1.00 \\
\hline Explained fitted variation (\%; cumulative) & 27.72 & 51.80 & 70.37 & 83.24 \\
\hline
\end{tabular}




\begin{tabular}{|c|c|}
\hline \multicolumn{2}{|l|}{$\begin{array}{c}\text { TABLE } 3 \\
\text { Acronyms used in CCA tri-plot (Fig.) }\end{array}$} \\
\hline Taxon & $\begin{array}{l}\text { Acro- } \\
\text { nym }\end{array}$ \\
\hline Planothidium lanceolatum (Brébisson) Lange-Bertalot & Alan \\
\hline Achnanthidium cf minutissimum & Amin \\
\hline Amphora copulata (Kützing) Schoeman and Archbald & Acop \\
\hline Amphora ovalis (Kützing) Kützing & Aova \\
\hline Brachysira serians (Brébisson) Round \& DG Mann & Aser \\
\hline Aulacoseira ambigua (Grunow) Simonsen & Aamb \\
\hline Aulacoseira granulata(Ehrenberg) Simonsen & Agra \\
\hline Aulacoseira muzzanensis (Meister) Krammer & Amuz \\
\hline Cocconeis placentula Ehrenberg & Cpla \\
\hline Cyclotella ocellata Pantocsek & Coce \\
\hline Cymbella tumida (Brébisson) Van Heurck & Ctum \\
\hline Diadesmis confervacea (Kützing) DG Mann & Dcon \\
\hline Diatoma vulgaris Bory & Dvul \\
\hline Diploneis ovalis (Hilse) Cleve & Dova \\
\hline Diploneis puella (Schumann) Cleve & Dpue \\
\hline Encyonema perpusillum (Cleve) Mann & Eper \\
\hline Eunotia bidentula Smith & Ebid \\
\hline Eunotia bilunaris (Ehrenberg) Mills & Ebil \\
\hline Eunotia formica Ehrenberg & Efor \\
\hline Eunotia sudetica Müller & Esud \\
\hline Fragilaria biceps (Kützing) & Fbic \\
\hline Fragilaria capucina Desmaziéres & Fcap \\
\hline Tabularia fasciculata (Agardh) Williams \& Round & Ffas \\
\hline Fragilaria pinnata Ehrenberg & Fpin \\
\hline Fragilaria tenera (Smith) Lange-Bertalot & Ften \\
\hline Fragilaria ulna (Nitzsch) Lange-Bertalot & Fuln \\
\hline Gomphonema accuminatum Ehrenberg & Gacc \\
\hline Gomphonema gracile Ehrenberg & Ggra \\
\hline Gomphonema affine Kützing & Gaff \\
\hline Gomphonema insigne Gregory & Gins \\
\hline Gomphonema minutum (Agardh) Agardh & Gmin \\
\hline Gomphonema parvulum (Kützing) Cleve & Gpar \\
\hline Gomphonema pseudoaugur Krammer & Gpse \\
\hline Gomphonema pumilum Reichardt \& Lange-Bertalot & Gpum \\
\hline Gomphonema truncatum Ehrenberg & Gtru \\
\hline Gomphonema venusta Passy, Kociolek \& Lowe & Gven \\
\hline Gyrosigma acuminatum (Kützing) Rabenhorst & Gacu \\
\hline Navicula gregalis Cholnoky & Ngre \\
\hline Navicula halophila( Grunow) Cleve & Nhal \\
\hline Navicula radiosa Kützing & Nrad \\
\hline Navicula recens (Lange-Bertalot) Lange-Bertalot & Nrec \\
\hline Navicula rhynchocephala Kützing & Nrhy \\
\hline Navicula tripunctata Müller Bory & Ntri \\
\hline Nitzschia dissipata (Kützing) Grunow & Ndis \\
\hline Nitzschia linearis (Agardh) Smith & Nlin \\
\hline Nitzschia palea (Kützing) Smith & Npal \\
\hline \begin{tabular}{|l|} 
Nitzschia pura Hustedt \\
\end{tabular} & Npur \\
\hline Pinnularia divergens Krammer & Pdiv \\
\hline Surirella linearis Smith & Slin \\
\hline
\end{tabular}

depending on anthropogenic activities taking place in the catchment. The expansion of Chinhoyi city does not meet the technical standards that go with it in terms of sewage treatment, collection of garbage, urban drainage, and so on. Streams in the study area, therefore, receive untreated or semi-treated effluent from various domestic and industrial sources as well as other diffuse sources as they pass through the city. This disorderly growth of the city, typical of many Zimbabwean cities, results in stream health deterioration, organic pollution and eutrophication, amongst other problems.

Diatom community structure and composition closely followed the observed changes in water quality due to urbanisation, as has been reported elsewhere (Lobo et al., 2004; Newall and Walsh, 2005; Duong et al., 2007; Smucker et al., 2013), with less polluted Sites 1 and 6 being associated with diatom communities that were different from highly polluted Sites 2, 5 and 7 where untreated sewage effluent was directly discharged into the streams leading to higher eutrophication and organic pollution. Different diatom species in a community respond differently to changes in pollution because of differences in tolerances. Therefore the composition of diatom communities at different locations, or at different points in time, provide useful information about the environmental conditions. As pollution (especially eutrophication and organic pollution) increased, low- or moderate-pollution- tolerant species, such as C. tumida, C. placentula, E. formica and E. perpusillum, were replaced by highly pollution-tolerant species such as, A. cf. minutissimum, A. muzzanensis, G. parvulum, G. gracile, G. pseudoaugur, N. gregalis and N. palea. The latter group of species have also been frequently recorded in waters that are nutrient rich and poorly oxygenated, with high electrical conductivity, variables that were retained in the CCA (Fig. 2) (Van Dam et al., 1994; Kobayasi and Mayama, 1998; Gómez and Licursi, 2001; Lobo et al., 2004; Taylor et al., 2007c; Bere and Tundisi, 2009, 2010b, 2011a, 2011b, 2011c). This group of species is known to be resistant to metal pollution (Duong et al., 2006). Lange-Bertalot (1979) stated that species are indicative of the upper limits of pollution that they can tolerate and not the lower limit. Thus, these species, which develop well in polluted zones, may also occur in fairly clean water. Their value as indicators is their presence in polluted water.

Patrick and Reimer (1966) pointed out the great difference between diatom communities in calcareous and calcium-poor rivers. In this study, diatom communities of Sites 3, 4 and 8, with high calcium levels, were different from the rest of the sites (Fig. 2). Calcium affects diatom motility and adhesion to surfaces (Cohn and Disparti, 1994), but exact physiological mechanisms responsible for the higher or lower affinity of diatoms to calcium (or the other alkaline cations) are still not known.

Vegetation cover, temperature and $\mathrm{pH}$ were also found to be important in structuring benthic diatom communities in the study area (Fig. 2). Vegetation cover has an effect on light intensity reaching the water surface and hence photosynthesis (Potapova and Charles, 2005). Temperature is an important driver of metabolic activities in benthic diatoms in lotic systems (Pan et al., 1996), while $\mathrm{pH}$ exerts a direct physiological stress on diatoms (Gensemer, 1991; Round, 2004), and also strongly influences other water chemistry variables (Stumm and Morgen, 1981).

\section{Applicability of borrowed indices}

Significant correlations between some diatom-based index scores and some physical and chemical characteristics of 


\section{TABLE 4}

Diatom index scores recorded for the following indices at 8 sites in streams draining Chinhoyi Town: ArtoisPicardie Diatom Index, APDI: Eutrophication/Pollution Index, EPI: Biological Diatom Index, BDI: Schiefele and Schreiner's Index. SHE: Saprobic Index, SI: Trophic Index, TI: Watanabe Index, WAT: Specific Pollution Densitivity Index, SPI: Sládeček's Index, SLA: Descy's Pollution Index, DES: Leclercq, IDSE: Generic Diatom Index, GDI: Commission of Economical Community Index, CEC: Trophic Diatom Index, TDI: Pampean Diatom Index, PDI: and Biological Index of Water Quality Trophic Index, BIWQ.

\begin{tabular}{|l|c|c|c|c|c|c|c|c|l|}
\hline & $\mathbf{1}$ & $\mathbf{2}$ & $\mathbf{3}$ & $\mathbf{4}$ & $\mathbf{5}$ & $\mathbf{6}$ & $\mathbf{7}$ & $\mathbf{8}$ & $\begin{array}{l}\text { Eutrophication/organic } \\
\text { load or water quality rates }\end{array}$ \\
\hline SLA & 2.1 & 2.3 & 2.0 & 1.9 & 2.1 & 2.1 & 2.2 & 2.0 & 0 (best) to 4 (worse) \\
\hline DES & 4.0 & 1.7 & 3.9 & 4.2 & 3.1 & 3.9 & 2.1 & 3.9 & 1 (worse) to 5 (best) \\
\hline IDSE & 3.6 & 2.6 & 3.8 & 3.6 & 3.1 & 3.3 & 2.5 & 3.6 & 1 (worse) to 5 (best) \\
\hline SHE & 5.0 & 2.6 & 4.4 & 5.2 & 3.5 & 5.0 & 2.1 & 4.3 & 1 (worse) to 7 (best) \\
\hline WAT & 77.0 & 20.6 & 32.8 & 47.6 & 43.0 & 62.7 & 36.9 & 40.5 & 0 (worse) to 100 (best) \\
\hline TDI & 64.0 & 79.3 & 40.0 & 65.6 & 70.7 & 67.5 & 93.0 & 57.0 & 0 (best) to 100 (worse) \\
\hline PT & 2.0 & 54.2 & 20.0 & 12.1 & 25.0 & 4.0 & 66.4 & 22.1 & 0 (best) to 100 (worse) \\
\hline GDI & 4.2 & 2.3 & 3.2 & 3.2 & 3.5 & 4.1 & 3.0 & 3.0 & 1 (worse) to 5 (best) \\
\hline CEE & 7.6 & 2.3 & 5.2 & 7.0 & 4.2 & 5.8 & 3.6 & 5.1 & 0 (worse) to 10 (best) \\
\hline SPI & 3.4 & 1.8 & 3.2 & 3.6 & 2.9 & 3.2 & 2.0 & 3.2 & 1 (worse) to 5 (best) \\
\hline BDI & 4.8 & 3.9 & 5.0 & 5.0 & 4.5 & 4.6 & 3.7 & 4.6 & 1 (worse) to 7 (best) \\
\hline APDI & 3.0 & 2.9 & 3.3 & 2.6 & 2.6 & 3.0 & 2.1 & 3.1 & 1 (worse) to 5 (best) \\
\hline EP1 & 1.8 & 2.1 & 1.6 & 1.5 & 1.7 & 1.9 & 1.8 & 1.2 & 0 (best) to 4 (worse) \\
\hline DICH & 4.3 & 6.6 & 5.1 & 3.6 & 5.9 & 4.9 & 6.6 & 4.3 & 1 (best) to 8 (worse) \\
\hline PDI & 1.9 & 3.0 & 1.9 & 2.1 & 2.6 & 1.9 & 3.2 & 1.8 & 0 (best) to 4 (worse) \\
\hline BIWQ & 2.3 & 3.8 & 2.8 & 2.1 & 2.9 & 2.4 & 3.2 & 3.0 & 1 (best) to 4 (worse) \\
\hline SI & 1.7 & 2.3 & 2.0 & 1.6 & 2.0 & 1.7 & 2.2 & 1.5 & 1 (best) to 3.8 (worse) \\
\hline TI & 2.6 & 3.2 & 2.6 & 2.6 & 2.8 & 2.7 & 3.2 & 2.4 & 0.3 (best) to 3.9 (worse) \\
\hline
\end{tabular}

\begin{tabular}{|c|c|c|c|c|c|c|c|c|c|c|c|}
\hline \multicolumn{12}{|c|}{ 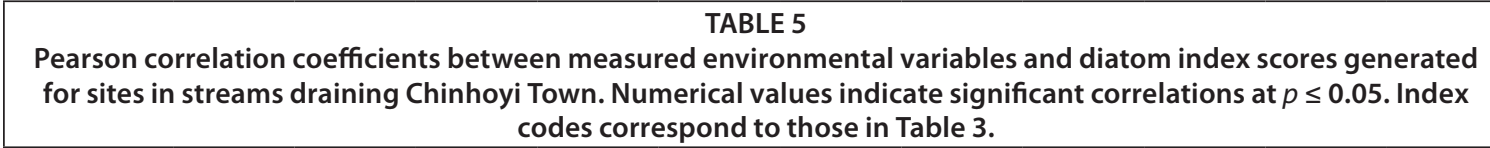 } \\
\hline & Temp & Cond & DO & $\mathrm{pH}$ & Turb & $\mathrm{NO}_{2}^{-}$ & $\mathrm{NH}_{4}^{+}$ & $\mathrm{PO}_{4}^{3-}$ & $\mathrm{Ca}^{2+}$ & $\mathrm{Fe}^{2+}$ & $\mathrm{Mn}^{2+}$ \\
\hline SLA & 0.64 & $\ldots$ & -0.71 & -0.45 & 0.84 & 0.82 & 0.88 & 0.88 & -0.71 & 0.86 & 0.79 \\
\hline DES & $\ldots$ & -0.52 & 0.93 & 0.66 & -0.93 & -0.95 & -0.98 & -0.92 & 0.42 & -0.83 & -0.90 \\
\hline \begin{tabular}{|l|} 
IDSE \\
\end{tabular} & -0.52 & $\ldots$ & 0.80 & 0.45 & -0.85 & -0.89 & -0.96 & -0.85 & 0.48 & -0.72 & -0.79 \\
\hline \begin{tabular}{|l|} 
SHE \\
\end{tabular} & $\ldots$ & -0.52 & 0.93 & 0.65 & -0.82 & -0.87 & -0.91 & -0.80 & $\ldots$ & -0.67 & -0.82 \\
\hline \begin{tabular}{|l} 
WAT \\
\end{tabular} & $\ldots$ & -0.86 & 0.85 & 0.95 & -0.65 & -0.63 & -0.61 & -0.62 & $\ldots$ & -0.63 & -0.72 \\
\hline TDI & 0.56 & 0.14 & -0.56 & -0.17 & 0.65 & 0.72 & 0.77 & 0.64 & $\ldots$ & 0.43 & 0.54 \\
\hline PT & $\ldots$ & 0.68 & -0.96 & -0.72 & 0.85 & 0.91 & 0.91 & 0.82 & $\ldots$ & 0.66 & 0.78 \\
\hline \begin{tabular}{|l|} 
GDI \\
\end{tabular} & $\ldots$ & -0.93 & 0.87 & 0.93 & -0.77 & -0.73 & -0.68 & -0.74 & $\ldots$ & -0.67 & -0.72 \\
\hline CEE & $\ldots$ & -0.42 & 0.51 & 0.47 & -0.40 & $\ldots$ & -0.44 & -0.45 & $\ldots$ & $\ldots$ & $\ldots$ \\
\hline \begin{tabular}{|l|} 
SPI \\
\end{tabular} & $\ldots$ & -0.53 & 0.92 & 0.65 & -0.94 & -0.96 & -0.99 & -0.94 & 0.43 & -0.85 & -0.87 \\
\hline BDI & -0.49 & $\ldots$ & 0.81 & 0.44 & -0.84 & -0.90 & -0.95 & -0.84 & 0.49 & -0.68 & -0.71 \\
\hline APDI & $\ldots$ & $\ldots$ & 0.41 & $\ldots$ & $\ldots$ & -0.44 & -0.48 & -0.26 & $\ldots$ & $\ldots$ & $\ldots$ \\
\hline \begin{tabular}{|l|} 
EP1 \\
\end{tabular} & 0.71 & $\ldots$ & -0.39 & $\ldots$ & 0.60 & 0.59 & 0.64 & 0.62 & -0.60 & 0.71 & 0.59 \\
\hline \begin{tabular}{|l|}
$\mathrm{DICH}$ \\
\end{tabular} & $\ldots$ & $\ldots$ & -0.84 & -0.58 & 0.77 & 0.81 & 0.88 & 0.76 & -0.56 & 0.74 & 0.85 \\
\hline \begin{tabular}{|l|} 
PDI \\
\end{tabular} & $\ldots$ & 0.48 & -0.89 & -0.61 & 0.84 & 0.90 & 0.93 & 0.81 & $\ldots$ & 0.69 & 0.86 \\
\hline \begin{tabular}{|l|} 
BIWQ \\
\end{tabular} & $\ldots$ & 0.60 & -0.88 & -0.76 & 0.83 & 0.81 & 0.83 & 0.84 & $\ldots$ & 0.80 & 0.83 \\
\hline SI & $\ldots$ & 0.48 & -0.86 & -0.70 & 0.80 & 0.82 & 0.84 & 0.77 & $\ldots$ & 0.80 & 0.90 \\
\hline \begin{tabular}{|l|} 
TI \\
\end{tabular} & 0.41 & 0.42 & -0.86 & -0.56 & 0.88 & 0.92 & 0.96 & 0.86 & -0.42 & 0.80 & 0.86 \\
\hline
\end{tabular}

streams recorded in this study indicate the success with which diatom indices may be used to reflect changes in water quality variables of the investigated waters. Results of Pearson's correlation between water quality variables and diatom indices obtained in the present study compared favourably with results for indices and water quality variables from some European (Prygiel and Coste, 1993; Kwandrans et al., 1998), South African (Taylor et al., 2007a,b) and Brazilian (Bere and Tundisi, 2012e) authors (Table 6). In some cases, the correlation coefficients were better than the correlations demonstrated in Europe and South Africa. 
TABLE 6

Pearson correlation coefficients between water chemistry variables and diatom indices from some Brazilian, European and South African authors. Numerical values indicate significant correlations at $p \leq 0.01$ or higher; ... = less significant correlations; * $=$ not measured. Abbreviations corresponded to those in Table 3.

\begin{tabular}{|l|c|c|c|c|c|c|c|c|c|c|c|c|c|c|c|c|c|c|}
\hline & SLA & DES & IDSE & SHE & WAT & TDI & GDI & CEC & SPI & BDI & APDI & EPI & DI-CH & PDI & BIWQ & SI & TI \\
\hline Bere and Tundisi, 20111 \\
\hline D0 & -0.92 & 0.92 & 0.92 & 0.94 & 0.85 & -0.95 & 0.93 & 0.71 & 0.94 & 0.91 & 0.81 & -0.91 & -0.85 & -0.89 & -0.86 & -0.94 & -0.83 \\
\hline Conductivity & 0.78 & -0.76 & -0.78 & -0.77 & -0.66 & 0.81 & -0.77 & -0.62 & -0.79 & -0.77 & -0.67 & 0.75 & 0.69 & 0.71 & 0.73 & 0.79 & 0.73 \\
\hline $\mathrm{pH}^{3-}$ & 0.76 & -0.86 & -0.82 & -0.78 & -0.72 & 0.82 & -0.78 & -0.74 & -0.80 & -0.83 & -0.73 & 0.78 & 0.86 & 0.82 & 0.85 & 0.82 & 0.82 \\
\hline $\mathrm{PO}_{4}{ }^{3-}$ & 0.68 & -0.75 & -0.74 & -0.79 & -0.75 & 0.72 & -0.74 & -0.66 & -0.76 & -0.75 & -0.79 & 0.76 & 0.75 & 0.78 & 0.69 & 0.76 & 0.70 \\
\hline $\mathrm{NH}_{4}^{+}$ & 0.84 & -0.80 & -0.80 & -0.79 & -0.93 & 0.78 & -0.84 & -0.63 & -0.81 & -0.81 & -0.82 & 0.86 & 0.77 & 0.83 & 0.77 & 0.80 & 0.69 \\
\hline $\mathrm{Ca}^{2+}$ & 0.85 & -0.90 & -0.88 & -0.83 & -0.91 & 0.85 & -0.88 & -0.77 & -0.87 & -0.90 & -0.89 & 0.90 & 0.88 & 0.89 & 0.89 & 0.87 & 0.85 \\
\hline
\end{tabular}

Taylor et al., 2007a

\begin{tabular}{|c|c|c|c|c|c|c|c|c|c|c|c|c|c|c|c|c|c|}
\hline Temperature & $\ldots$ & * & $\ldots$ & $\ldots$ & $\ldots$ & $\ldots$ & $\ldots$ & $\ldots$ & $\ldots$ & $\ldots$ & $\ldots$ & $\ldots$ & * & * & * & * & $\ldots$ \\
\hline Conductivity & 0.54 & * & 0.53 & 0.52 & -0.40 & 0.66 & 0.55 & 0.52 & 0.48 & 0.6 & -0.53 & 0.56 & * & * & * & * & 0.55 \\
\hline $\mathrm{pH}$ & 0.25 & * & 0.36 & 0.31 & $\ldots$ & 0.31 & 0.55 & 0.42 & -0.4 & 0.49 & -0.34 & 0.3 & * & * & * & * & 0.29 \\
\hline $\mathrm{PO}_{4}^{3-}$ & 0.41 & * & 0.48 & 0.45 & -0.45 & 0.28 & 0.28 & 0.45 & 0.44 & 0.3 & -0.49 & 0.55 & * & * & * & * & 0.49 \\
\hline $\mathrm{NO}_{3}^{-}+\mathrm{NO}_{2}^{-}$ & 0.59 & * & 0.51 & 0.59 & -0.49 & 0.55 & 0.23 & 0.45 & 0.5 & 0.4 & -0.50 & 0.55 & * & * & * & * & 0.63 \\
\hline $\mathrm{NH}_{4}^{+}$ & 0.39 & * & 0.4 & 0.39 & $\ldots$ & 0.18 & 0.25 & 0.39 & 0.51 & 0.28 & -0.29 & 0.27 & * & * & * & * & 0.28 \\
\hline $\mathrm{Ca}^{2+}$ & 0.48 & * & 0.44 & 0.45 & -0.29 & 0.59 & 0.42 & 0.45 & 0.42 & 0.45 & -0.43 & 0.48 & * & * & * & * & 0.45 \\
\hline
\end{tabular}

Taylor et al., 2007

\begin{tabular}{|c|c|c|c|c|c|c|c|c|c|c|c|c|c|c|c|c|c|}
\hline $\mathrm{pH}$ & $\ldots$ & $\ldots$ & $\ldots$ & $\ldots$ & $\ldots$ & * & $\ldots$ & -0.32 & $\ldots$ & -0.35 & -0.25 & $\ldots$ & * & * & * & $*$ & * \\
\hline Conductivity & -0.48 & $\ldots$ & -0.48 & $\ldots$ & -0.46 & * & -0.37 & -0.52 & -0.05 & -0.63 & -0.42 & -0.44 & * & * & * & $*$ & * \\
\hline Temperature & $\ldots$ & -0.27 & $\ldots$ & -0.27 & -0.51 & * & -0.29 & -0.27 & -0.35 & $\ldots$ & $\ldots$ & -0.36 & * & * & * & * & * \\
\hline DO & $\ldots$ & $\ldots$ & $\ldots$ & $\ldots$ & $\ldots$ & * & $\ldots$ & $\ldots$ & $\ldots$ & $\ldots$ & $\ldots$ & $\ldots$ & * & * & * & $*$ & * \\
\hline Turb & 0.31 & $\ldots$ & 0.25 & $\ldots$ & $\ldots$ & * &. &.. & $\ldots$ & 0.32 & $\ldots$ & $\ldots$ & * & * & * & * & * \\
\hline \multicolumn{18}{|c|}{ Kwandrans et al., 1998} \\
\hline Conductivity & $\ldots$ & -0.75 & -0.69 & -0.71 & * & * & -0.73 & -0.69 & -0.75 & * & -0.56 & * & * & * & * & * & * \\
\hline DO & $\ldots$ & 0.6 & 0.62 & 0.7 & * & * & 0.68 & 0.61 & 0.62 & * & 0.5 & * & * & * & * & $*$ & * \\
\hline $\mathrm{NH}_{4}^{+}$ & $\ldots$ & -0.76 & -0.7 & -0.71 & * & * & -0.71 & -0.72 & -0.72 & * & -0.55 & * & * & * & * & * & * \\
\hline $\mathrm{NO}_{3}^{-}$ & $\ldots$ & 0.42 & $\ldots$ & $\ldots$ & * & * & $\ldots$ & $\ldots$ & $\ldots$ & * & $\ldots$ & * & * & * & $*$ & $*$ & * \\
\hline $\mathrm{PO}_{4}^{3-}$ & $\ldots$ & -0.52 & -0.57 & $\ldots$ & * & * & -0.51 & -0.62 & -0.51 & * & $\ldots$ & * & * & * & * & * & * \\
\hline \multicolumn{18}{|c|}{ Prygiel\&Coste (1993) } \\
\hline Conductivity & $\ldots$ &.. & 0.11 & * & * & * & 0.21 & 0.19 & 0.17 & * & * & * & * & * & * & $*$ & * \\
\hline $\mathrm{NH}_{4}^{+}$ & 0.4 & 0.4 & 0.46 & * & * & * & 0.29 & 0.4 & 0.41 & * & * & * & * & * & $*$ & $*$ & * \\
\hline $\mathrm{NO}_{2}^{-}$ & 0.34 & 0.37 & 0.35 & * & * & * & 0.16 & 0.37 & 0.35 & * & * & * & * & * & * & $*$ & * \\
\hline $\mathrm{pH}$ & 0.22 & 0.16 & 0.22 & * & * & * & $\ldots$ & 0.16 & 0.15 & * & * & * & * & * & * & $*$ & * \\
\hline $\mathrm{PO}_{4}^{3-}$ & 0.4 & 0.5 & 0.52 & * & * & * & 0.4 & 0.5 & 0.54 & * & * & * & * & * & * & $*$ & * \\
\hline DO & 0.39 & 0.37 & 0.44 & * & * & * & 0.27 & 0.37 & 0.38 & * & * & * & * & * & * & $*$ & * \\
\hline Temperature & 0.33 & 0.35 & 0.35 & * & * & * & 0.22 & 0.35 & 0.36 & * & * & * & * & * & * & * & * \\
\hline
\end{tabular}

Although there may be concerns as to the feasibility of transferring data concerning the ecological tolerance limits of diatoms between the Northern and Southern Hemispheres, most of the dominant diatom species encountered in this study are cosmopolitan species well documented in international literature, especially from the Northern Hemisphere (e.g. Krammer and Lange-Bertalot, 1986-1991). These results are in agreement with Bate et al. (2004) who found that most dominant diatom species found in South African rivers were already recorded in international literature. For that reason, most foreign diatom indices may be used in the study area as they are based on the ecology of widely distributed or cosmopolitan taxa.

A total of 24 species (about 25\% of the species recorded during the study, some of them probably endemic to the study region) were not entered into OMNIDIA for calculation of indices. Ecological preferences of these relatively rare diatom species have yet to be determined, rendering them useless in the calculation of index scores using OMNIDIA. Incorporation of these rare taxa in index calculation may give a better picture of the investigated water. Besides omission of about $25 \%$ of the species recorded in the calculation of the indices, the autecology of some species recorded in this study, such as G. parvulum and $N$. palea, are still controversial. For example, recent evidence from the study by Trobajo et al. (2009) suggests that $N$. palea is taxonomically problematic. Their work illustrated that $N$. palea is almost certainly a complex of several or many separate species, which may differ subtly in morphology and may not all share the same ecology. Detailed studies of species with uncertain autecology are called for in order to clarify their taxonomy and ecological requirements. Round (2004) discovered that lumping of several similarl-looking taxa into one 'morphospecies' diminishes discriminative ability of diatom metrics, while detailed taxonomic and ecological studies allow 
recognition of taxa with good indicator properties.

The ongoing discussion demonstrates the inconsistency and lack of appropriate information on ecological requirements of some diatom species recoded in this study, hampering formulation of sound diatom-based water quality management protocols. More work is needed to elucidate the ecological requirements of some diatoms in Zimbabwe, something that is far from being understood. There is a need, for a start, for extensive surveys to provide a geographical framework of diatom distributional data related to broad-scale climatic, vegetation and geological distribution patterns in Zimbabwe. Meanwhile, as recommended by Taylor et al. (2007a), foreign indices can be used to (i) gain support and recognition for diatom-based approaches to water quality monitoring in Zimbabwe, (ii) provide an indication of water quality and allowing for the dissemination of simplified useful information to resource managers, conservationists and the general public, and (iii) allow for sample and data collection which can then be used later in the formulation of a diatom-based water quality assessment index tailored for Zimbabwe, as well as taxonomic and biogeographic studies.

Some diatom indices which exhibited consistent classifications and strong correlations with water quality variables such as TI, SI, PDI, BIWQ and IDSE indices are recommended for use in the country. All of these indices are designed to monitor organic enrichment and eutrophication (Leclerq and Maquet, 1987; Rott et al., 1997; Rott et al., 1999; Gómez and Licuirsi, 2000; Lobo et al., 2004), two phenomena which can hardly be separated and were common in the study area as well as most streams draining urban areas in Zimbabwe, due to a breakdown of municipal sewage effluent handling infrastructure. The TI index, which exhibited strongest correlations with environmental variables, as well as the BIWQ and PDI indices, developed in the tropical regions (Gómez and Licuirsi, 2000; Lobo et al., 2004), are especially recommended.

\section{CONCLUSIONS}

Assessment of water quality based on diatom-based indices is deemed useful in Zimbabwe to provide information on water quality impacts on rivers and streams for management purposes. Although all borrowed indices were generally applicable to the study area because many widely distributed diatom species have similar environmental tolerances to those recorded for these species elsewhere, ecological requirements of some diatom species from Zimbabwe need to be clarified and incorporated in a diatom-based water quality assessment protocol unique to the country. Certain species like A. cf. minutissimum, A. muzzanensis, G. parvulum, G. gracile, G. pseudoaugur, N. gregalis and $N$. palea, associated with the pollution extremes, especially eutrophication, may be used in future studies as potential indicator species for these variable changes. These species can be subjected to further experiments to confirm their status as indicator species. In addition, the applicability of these diatom-based indices needs to be tested across different geographical and climatic regions in the country and disparities among the regions compared, as this study just focused on an urban area in one geographic region. Resources should be channelled towards tackling challenges associated with diatom-based biological monitoring, principally taxonomic studies (major challenge of the present study), training of skilled manpower, and acquiring and maintaining the necessary infrastructure. There is a need for establishment of networks of competence at national, regional and global levels to improve diatom-based biological monitoring through research and innovative practices that are ecologically oriented. This should be followed by fostering two-way interactions between scientists, on the one hand, and the general public and decision makers, on the other.

\section{ACKNOWLEDGEMENTS}

This study was made possible by the provision of funds from International Foundation for Science (IFS).

\section{REFERENCES}

APHA (1988) Standard Methods for the Examination of Water and Waste Water (20th edn.). American Public Health Association, Washington D.C.

AZIM ME, VERDEGEM MCJ, VAN DAM AA and BEDERIDGE MCM (2005)Periphyton ecology, exploitation and management. CABI Publishing, Cambridge.

BATE G, SMAILES P and ADAMS J (2004) A water quality index for use with diatoms in the assessment. Water SA 30 493-498.

BERE T and TUNDISI JG (2009) Weighted average regression and calibration of conductivity and $\mathrm{pH}$ of benthic diatom assemblages in streams influenced by urban pollution. Acta Limnol. Bras.12 317-325.

BERE T and TUNDISI JG (2010a) Biological monitoring of lotic ecosystems: the role of diatoms. Braz. J. Biol. 70 493-502.

BERE T and TUNDISI JG (2010b) Epipsammic diatoms in streams influenced by urban pollution. Braz. J. Biol. 70 921-930.

BERE T and TUNDISI JG (2011a) Influence of ionic strength and conductivity on benthic diatom communities in a tropical river (Monjolinho), São Carlos-SP, Brazil. Hydrobiologia 661 261-276.

BERE T and TUNDISI JG (2011b) Influence of land-use patterns on benthic diatom communities and water quality in the tropical Monjolinho hydrological basin, São Carlos-SP, Brazil. Water SA 37 93-102.

BERE T and TUNDISI JG (2011c) The effects of substrate type on diatom-based multivariate water quality assessment. Water Air Soil Pollut. 216 391-409.

BERE T and TUNDISI JG (2011d) Applicability of the Pampean Diatom Index (PDI) to streams around São Carlos-SP, Brazil. Ecol. Indic. 13 342-346.

BERE T and TUNDISI JG (2011e) Applicability of borrowed diatombased water quality assessment indices in streams around São Carlos-SP, Brazil. Hydrobiologia 673 193-204.

BIGGS BJF and KILROY C (2000) Stream Periphyton Monitoring Manual. NIWA, Christchurch, New Zealand.

CEMAGREF (1982) Etude des methods biologiques d'appréciation quantitative de la qualité Des eaux. Rapport Q. E. Lyon, Agence de l'eau Rhône-Méditerranée-Corse- Cemagref, Lyon, France.

CHESSMANA BC and TOWNSEND SA (2010) Differing effects of catchment land use on water chemistry explain contrasting behaviour of a diatom index in tropical northern and temperate southern Australia. Ecol. Indic. 10 620-626.

COHN SA and DISPARTI NC (1994) Environmental factors influencing diatom cell motility. J. Phycol. 30 818-828.

COSTE M and AYPHASSORHO H (1991) É tude de la qualité dês eaux du Bassin Artois-Picardie à l'aide des communaute's de diatomées benthiques (application des índices diatomiques). Rapport Cemagref, Bordeaux. Agence de l'Eau Artois-Picardie, Douai.

DELL'UOMO A (1996) Assessment of water quality of an Apennine river as a pilot study. In: Whitton BA and Rott $\mathrm{E}$ (eds.) Use of Algae for Monitoring Rivers II. Institut für Botanik, Universität Innsbruck, Innsbruck. 65-73.

DESCY JP and COSTE M (1991) A test of methods for assessing water quality based on diatoms. Verh. Internat. Verein. Theor. Angew. Limnol. 24 2112-2116.

DESCY JP (1979) A new approach to water quality estimation using diatoms. Nova Hedwigia 64 305-323.

DOUNG TT, FEURTET-MAZAL A, COSTE M, DANG DK and 
BOUDOU A (2007) Dynamics of diatom colonization processes in some rivers influenced by urban pollution (Hanoi, Vietnam). Ecol. Indic. 7 839-851.

DUONG T, COSTE M, FEURTET-MAZEL A, DANG D, GOLD C, PARK Y and BOUDOU A(2006) Impact of urban pollution from the Hanoi area on benthic diatom communities collected from the Red, Nhue and Tolich Rivers (Vietnam). Hydrobiologia 563 201-216.

GÓMEZ N and LICURSI M (2001) The Pampean Diatom Index (Idp) for assessment of rivers and streams in Argentina. Aquat. Ecol. 35 $173-181$.

GENSEMER RW (1991) The effects of pH and aluminum on the growth of the acidophilic diatom Asterionellaralfsii var. americana. Limnol. Oceanogra. 36 123-131.

HAMMER O, HARPER DAT and RYAN PD (2012) PAST - Palaeontological Statistics, version 2.16. URL: http://folk.uio.no/ohammer/ past (Accessed 10 December 2012).

HARDING WR, ARCHIBALD CGM and TAYLOR JC (2005) The relevance of diatoms for water quality assessment in South Africa: A position paper. Water SA 31 41-46.

KELLY MG and WHITTON BA (1995) The trophic diatom index: a new index for monitoring eutrophication in rivers. J. Appl. Phycol. 7 433-444.

KOBAYASI H and MAYAMA S (1989) Most pollution-tolerant diatoms of severely polluted rivers in the vicinity of Tokyo Japan. J. Phycol. 30 188-196.

KRAMMER K and LANGE-BERTALOT H (1986-1991) Süßwasserflora von Mitteleuropa. Band 2. Bacillariophyceae. Teil 1-4. Gustav Fischer Verlag, Stuttgart.

KWANDRANS J, ELORANTA P, KAWECKA B and KRYZSYSZTOF W (1998) Use of benthic diatom communities to evaluate water quality in rivers of southern Poland. J. Appl. Phycol. 10 193-201.

LANGE-BERTALOT H (1979) Pollution tolerance of diatoms as criteria for water quality estimation. Nova Hedwigia 64 283-304.

LAVOIE S, CAMPEAU S, DARCHAMBEAU F, CABANA F and DILLON PJ (2008) Are diatoms good integrators of temporal variability in stream water quality? Freshwater Biol. 53 827-841.

LECLERQ L and MAQUET B (1987) Deux nouveaux índices chimique et diatomique de qualité d'eau courante:Application au Samson et à sesaffluents (bassin de la Meuse belge). Comparaison avec d'autresíndiceschimiques, biocénotiquesetdiatomiques. Institut Royal des Sciences Naturelles de Belgique, document de travail 28

LECOINTE C, COSTE M and PRYGIEL J (1993) 'Omnidia': Software for taxonomy, calculation of diatom indices and inventories management. Hydrobiologia 269/270 509-513.

LENOIR A and COSTE M (1996) Development of a practical diatom index of overall water quality applicable to the French National Water Board network In: Whitton BA and Rott E (eds.) Use of Algae for Monitoring Rivers II. Institut für Botanik, Universität Innsbruck.

LOBO EA, CALLEGARO VL, HERMANY G, BES D, WETZEL CE and OLIVEIRAMA (2004) Use of epilithic diatoms as bioindicator from lotic systems in southern Brazil, with special emphasis on eutrophication. Acta Limnol. Bras.16 25-40.

McCORMICK PV and CAIRNS JJ (1994) Algae as indicators of environmental change. J. Appl. Phycol. 6 509-526.

METZELTIN D and LANGE-BERTALOT H (2007) Tropical Diatoms of South America II. Iconogr. Diatomol. 18 1-877.

METZELTIN D and LANGE-BERTALOT H (1998) Tropical Diatoms of South America I. Iconogr. Diatomol. 5 1-695.

NEWALL P and WALSH CJ (2005) Response of epilithic diatom assemblages to urbanization influences. Hydrobiologia 532 53-67.

PAN Y, STEVENSON RJ, HILL BH, HERLIHY AT and COLLINS GB (1996) Using diatoms as indicators of ecological conditions in lotic systems: a regional assessment. J. N. Am. Benthol. Soc. 15 481-495.

PAPPAS JL and STOERMER EFF (1996) Quantitative method for determining a representative algal sample count. J. Phycol. 32 693-696.

PATRICK R and REIMER CW (1966) The Diatoms of the United States. Academy of Natural Sciences, Philadelphia. 688 pp.

PIPP E (2002) A regional diatom-based trophic state indication system for running water sites in Upper Austria and its overregional applicability. Verhand.der Internat. Ver. Für Limnol. 27 3376-3380.

PHIRI C, DAY J, CHIMBARI M and DHLOMO E (2007) Epi-

phytic diatoms associated with a submerged macrophyte, Vallisneriaaethiopica, in the shallow marginal areas of Sanyati Basin (Lake Kariba): a preliminary assessment of their use as biomonitoring tools. Aquat. Ecol. 41 169-181.

POTAPOVA MG and CHARLES DF (2007) Diatom metrics for monitoring eutrophication in rivers of the United States. Ecol. Indic. 7 $48-70$

POTAPOVA MG and CHARLES DF (2002) Benthic diatoms in USA Rivers: distributions along speciation and environmental gradients. J. Biogeogr. 29 167-187.

PRYGIEL J and COSTE M (1993) The assessment of water quality in the Artois-Picardie water basin (France) by the use of diatom indices. Hydrobiologia 269/279 343-349.

PRYGIEL J, LÉVÉQUE L and ISERENTANT R (1996) Un nouvel indice diatomique pratique pour l'évaluation de La qualité des eaux en réseau de surveillance. Revue dês Sciences de l'Eau 1 97-113.

RIMET F, ECTOR L, CAUCHIE HM and HOFFMANN L (2004) Regional distribution of diatom assemblages in the headwater streams of Luxembourg. Hydrobiol. 520 105-117

ROTT E, HOFMANN G, PALL K, PFISTER P and PIPP E (1997) Indikationslisten für Aufwuchsalgen. Teil 1.SaprobielleIndikation. Bundesministeriumfür Land- und Forstwirtschaft, Wien. 1-73.

ROTT E, PIPP E, PFISTER P, VAN DAM H, ORTLER K, BINDER $\mathrm{N}$ and PALL K (1999) Indikationslistenfür Aufwuchsalgen in ö sterreichischen Fliessgewässern. Teil 2: Trophieindikation (sowiegeochemische Präferenzen; taxonomische und toxikologische Anmerkungen). Wasserwirtschaftskatasterherasgegebenvom Bundesministerium f. Land- u. Forstwirtschaft, Wien. ISBN: 3-85 174-25-4 248.

ROUND FE (2004) pH scaling and diatom distribution. Diatom Res. 20 9-12.

SCHIEFELE S and SCHREINER C (1991) Use of diatoms for monitoring nutrient enrichment acidification and impact salts in Germany and Austria. In: Whitton BA, Rott E, Friedrich G (ed.) Use of Algae for Monitoring Rivers. Institüt für Botanik, Univ. Innsbruck, Innsbruck.

SLÀDEČEK V (1986) Diatoms as indicators of organic pollution. Acta Hydrochim. Hydrobiol. 14 555-566.

SMUCKER NJ and VIS ML (2011) Diatom biomonitoring of streams: Reliability of reference sites and the response of metrics to environmental variations across temporal scales. Ecol. Indic. 11 1647-1657.

SMUCKER NJ, DETENBECK NE and MORRISON AC (2013) Diatom responses to watershed development and potential moderating effects of near-stream forest and wetland cover. Freshwater Sci. 32 230-249.

STENGER-KOVÁCSA C, LENGYELA E, CROSSETTIB LO, ÜVEGESA V and PADISÁK J (2013) Diatom ecological guilds as indicators of temporally changing stressors and disturbances in the small Torna-stream, Hungary. Ecol. Indic. 24 138-147.

STUMM W and MORGAN JJ (1981) Aquatic Chemistry: An Introduction Emphasizing Chemical Equilibria in Natural Waters. WileyInterscience, New York. 789 pp.

TAYLOR JC, JANSE VAN VUUREN MC and PIETERSE AJH (2007b) The application and testing of diatom-based indices in the Vaal and Wilge Rivers, South Africa. Water SA 33 51-59.

TAYLOR CJ, PRYGIEL AV, DE LA REY PA and VAN RENSBURG S (2007a) Can diatom-based pollution indices be used for biological monitoring in SA? A case study of the Crocodile West and Marico water management area. Hydrobiologia 592 455-464.

TAYLOR JC, ARCHIBALD CGM and HARDING WR (2007c) An Illustrated Guide to Some Common Diatom Species from South Africa. Water Research Commission Report No. TT 282/07. Water Research Commission, Pretoria. 210 pp.

TER BRAAK CJF and VERDONSCHOT PFM (1995) Canonical correspondence analysis and related multivariate methods in aquatic ecology. Aquat. Sci. 37 130-137.

TER BRAAK CJF and ŠMILAUER P (2002) CANOCO Reference Manual and CanDraw for Windows User's Guide: Software for community ordination version 4.5. Microcomputer Power, Ithaca, New York.

http://dx.doi.org/10.4314/wsa.v40i3.14

Available on website http://www.wrc.org.za

ISSN 0378-4738 (Print) = Water SA Vol. 40 No. 3 July 2014

ISSN 1816-7950 (On-line) = Water SA Vol. 40 No. 3 July 2014 
TROBAJO R, CLAVERO E, CHEPURNOV VA, SABBE K, MANN DG, ISHIHAR S and COX EJ(2009) Morphological, genetic and mating diversity within the widespread bioindicator Nitzschiapalea (Bacillariophyceae). Phycologia 48 443-459.

VAN DAM H, MERTENS A and SINKELDAM J (1994) A coded checklist and ecological indicator values of freshwater diatoms from The Netherlands. Aquat. Ecol. 28 117-133.

WATANABE T, ASAI K and HOUKI A (1986) Numerical estimation of organic pollution of flowing waters by using the epilithic diatom assemblage - Diatom Assemblage Index (DIApo). Sci. Total Environ. 55 209-218.

WEHR JD and SHEATH RG (2003) Freshwater Algae of North America, Ecology and Classification.Academic Press, San Diego. $918 \mathrm{pp}$.

ZELINKA M and MARVAN P (1961) Zurprasisiering der biologischenklassifikation der reinheotfliessendergewässer. Archive Hydrobiol. 57 389-407.

ZAR JH (1984) Biostatistical Analysis. Prentice Hall, New Jersey. 